\title{
A DÉL-TISZA-VÖLGY LAKOSSÁGÁNAK KÖRNYEZETI TUDATA
}

\author{
(The Environmental Consciousness of Population \\ of South-Tisza-Valley)
}

KOVÁCS ANDRÁS DONÁT

Kulcsszavak:

környezeti rendszerek településkörnyezet kulturális-mentalis környezet környezeti tudat

Környezetünk fenntarthatóságának megörzésében a társadalom gondolkodása alapvetóen meghatározó lehet. Ahhoz, hogy az emberek környezethez való viszonyát megértsilk és a környezetállapot javitását célzó megoldási lehetỏségeket kidolgozzuk, nélkülözhetetlen a kulturális-mentális környezet megismerése. A Tisza folyó környezetének megújulása kapcsán, a társadalom környezeti értékekról alkotott tudati „vetületeinek" bemutatása ezért idöszerü ês fontos feladat.

\section{Bevezetés}

A múlt év februárjában, megfelelő kontroll nélküli bányászati-ipari tevékenységből fakadóan bekövetkezett a hazánkat érintỏ eddigi, talán legsúlyosabb folyamszennyezési katasztrófa. Az ausztrál-román közös érdekeltségủ Aurul S. A. részvénytársaság Nagybányán működő üzeméböl százezer köbméter ciántartalmú zagy került a Lápos patakon keresztül a Szamosba, majd a Tiszába (Bognár 2000; $S$ Ráduly 2000; Horváth 2000). A folyó felsỏ szakaszán mért 32,6 milligrammos literenkénti ciántartalom rendkívüli mértékủ, hirtelen halpusztulást okozott, de a drasztikus környezeti csapásnak valójában ez csak az elsỏ megnyilvánulása volt. A cianid a táplálékláncba bekerülve veszélybe sodorta a folyó menti ökológiai folyosó élỏvilágát, sőt mivel a méreg elérte az ivóvízbázist, a folyó menti lakosság vízfogyasztása is kockázatossá vált (Gallé 2000; Bellon 2000; Mezösi 2000).

A tiszai ciánszennyezés a környezeti konfliktusok elrettentő esete, melyben a növény- és állatvilág „ártatlan” képviselöi mellett maga az ember is áldozat. A természet azonnali és „látványos” reakciójának következtében néhány nap alatt egy egész ország szembesülhetett a felelötlenségböl fakadó hatalmas kárral. Felmerül a kérdés, hogy a települések közvetlen környezetében lezajlott események; az élövilág pusztulása, s annak egész tiszai ökoszisztémát érintö hatása, ráébresztették-e a lakosságot arra, hogy az ember és környezete elválaszthatatlan egységet képez?

A tragédia nem csupán a nemzetközi szerződések elkerülhetetlenségére, a környezetvédelmi jog minél előbb pótlandó hézagaira, de a folyó mentén élők kiszolgáltatottságára, a térség többszörösen összetett környezeti problémáira és a társadalom környezeti-felelősségérzetének fontosságára is felhívta a figyelmet.

Kétségtelen - alvízi ország lévén -, a folyó menti térségek sok esetben tehetetlenek a felvízi szennyezőkkel szemben. Azonban a tiszai élőhelyek, települések kör- 
nyezetének fenntarthatóságában a lakosság „öntudatra ébredése”, modern szemléletü környezeti tudásának gyarapodása a jövőben legalább olyan meghatározó lesz, mint a nemzetközi, országos vagy a regionális környezetpolitika elkerülhetetlen reformjai.

Mivel a folyó magyarországi szakaszának jövöjéért elsősorban a hazai, a Tiszaparti településeknek kell garanciát vállalniuk, a környezeti tevékenységek mind a helyi vezetök, mind a lakosság részéről nagyfokú tudatosságot igényelnek. Ezért nélkülözhetetlen a környezettel kapcsolatos gondolatok, társadalmi magatartásformák, viselkedési minták megértése, a környezetállapot javítását célzó megoldási lehetőségek kidolgozásához szükséges - megfelelö módszerekkel lehatárolt - környezeti referenciaállapot megismerése és a társadalom környezeti értékekröl alkotott tudati „vetületeinek” bemutatása.

Kutatásunk során a Dél-Tisza-völgy északi területei föbb környezeti problémáinak bemutatásán túl, az ottani lakosság környezeti tudatát, környezethez való viszonyát, a környezeti problémák iránti érzékenységét és fogékonyságát, lokális kötődését és közérzetét vizsgáltuk meg.

\section{Környezet, településkörnyezet, környezeti tudat}

"A civil társadalom nem háríthat át minden feladatot az államra, tagjainak maguknak is cselekedniök kell, - Jövönkért mindannyian, külön-külön és egyénileg is felelösek vagyunk!" (Herczegh Géza)

A „környezet” szó, a médiában és a hétköznapi szóhasználatban legtöbbször, az aktuális környezeti politikák, vagy a környezetvédelem által meghatározott feladatok kapcsán hallható, a környezettel foglalkozó tudományterületek pedig elsősorban a természeti értékeket, a gazdasági fenntarthatóságot kihangsúlyozva alakították ki a környezetre vonatkozó saját fogalmi rendszerüket. (Az ökológia és a közgazdaságtan a környezet fogalmát a környezetvédelem, a fenntartható fejlödés és a környezetgazdálkodás definícióiban említi leggyakrabban.)

A geográfia rendszerszemlélete szerint a környezetet a természetes és a mesterséges rendszerek összességeként kell értelmeznünk. A környezetet alkotó rendszerek többszörösen összetettek. Részrendszereik és azok elemei bonyolult funkcionális és szerkezeti kapcsolatban állnak egymással (Kerényi 1995). A környezetünket alkotó térsruktúrák egymásra hierarchikusan épülve „ölelik” körül a külvilággal szemben álló személyt, vagyis a szubjektumot. Az ember az öt körulvevő környezeti rendszert részleteiben érzékeli, s távolodva a személyes terétöl egyre kevésbé ismeri azt (1.ábra). 
Kovács András Donát: A Dél-Tisza-völgy lakosságának környezeti tudata.

Tér és Társadalom, 15. 2001. 3-4. 161-179. p

TÉT XV. évf. 2001 -3-4

Gyors ténykép

163

\section{1. ÁBRA}

A környezeti terek és az ismeretek csökkenése a tér bövülésével

(The Decrease of Environmental Spaces and Knowledge with the Expansion of Space)

- a szubjektum által ismert környezeti rendszerrészek, részelemek

$\square$ a szubjektum által nem ismert környezeti rendszerrészek

A globális környezet és elemei

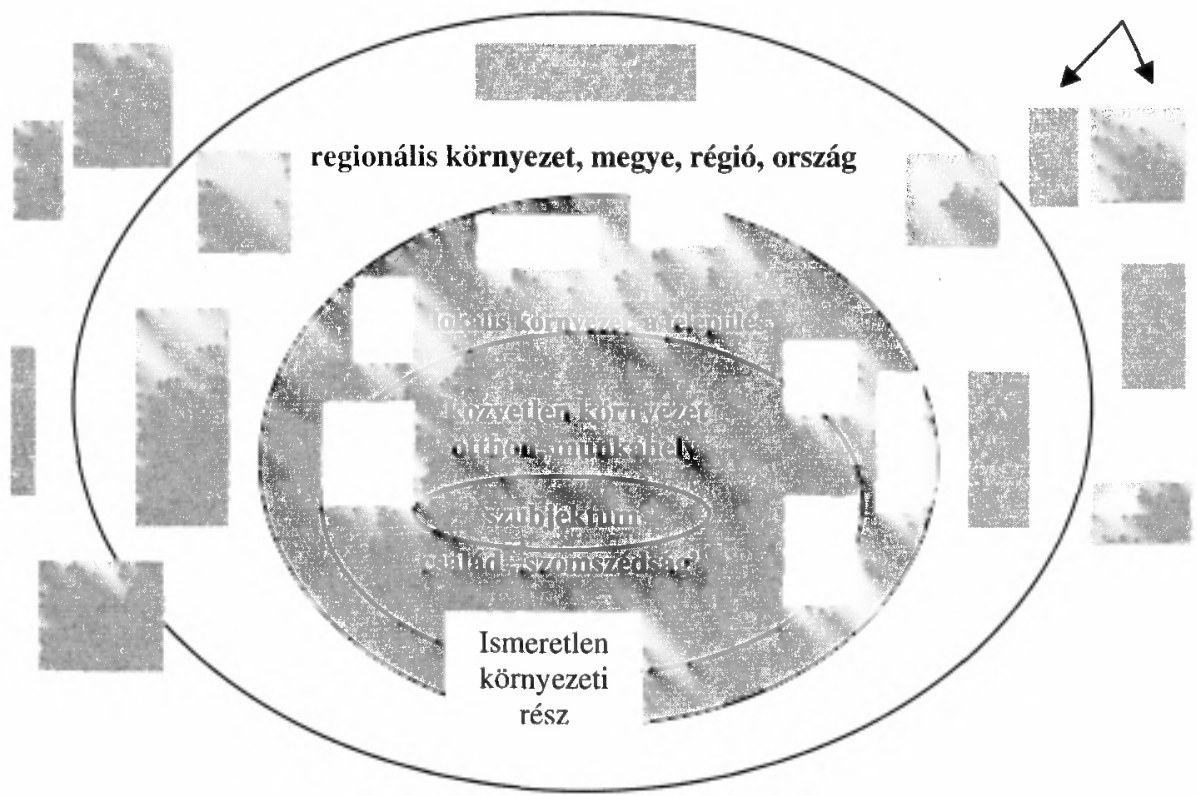

Forrás: Saját szerkesztés.

A legtöbb ember a környezet szó hallatán közvetlen környezetére, az adott lakóhelyére, munkahelyére, az otthonára, annak is főképp fizikai vonatkozásaira, a természeti környezetre és az épített környezetre asszociál. Kétségtelen, hogy a környezethez való viszonyulásban ennek van a legnagyobb jelentősége. Mégis figyelembe kell vennünk, hogy valojában egy tágabb, a lokális tényezőkön túlmutató regionális, sỏt globális környezet vesz bennünket körül.

Ahhoz, hogy az emberek környezethez való viszonyát megértsük, meg kell határoznunk, hogy a tájstruktúrák, a természeti, a társadalmi környezeti elemek, vagy a települések oldaláról közelíthetjük meg az „ember és környezet kapcsolat” problémakört. Mivel a társadalmi és gazdasági tevékenységek fö színtereit a települések jelentik, a településkörnyezeti rendszerekből indulunk ki. A településkörnyezet fö alrendszerei: a természetes és az átalakított környezet, az épített, a gazdasági és a kulturális-mentális környezet (Enyedi 2000) (2. ábra). 
2. ÁBRA

A településkörnyezeti rendszer alrendszerei Enyedi György alapján (Subsystems of the Urban Environmental System by György Enyedi)

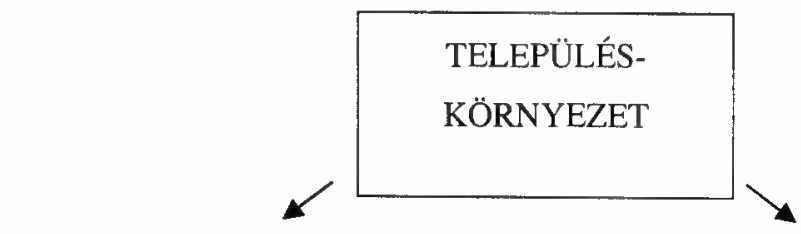

\begin{tabular}{|l|l|}
\hline Természeti-földrajzi környezet & Társadalmi-gazdasági környezet \\
\hline
\end{tabular}

\begin{tabular}{|c|c|c|c|c|}
\hline $\begin{array}{c}\text { Természetes } \\
\text { környezet }\end{array}$ & $\begin{array}{c}\text { Átalakított } \\
\text { környezet }\end{array}$ & $\begin{array}{c}\text { Épített } \\
\text { környezet }\end{array}$ & $\begin{array}{c}\text { Gazdasági } \\
\text { környezet }\end{array}$ & $\begin{array}{c}\text { Kulturális- } \\
\text { mentális } \\
\text { környezet }\end{array}$ \\
\hline
\end{tabular}

Forrás: Enyedi 2000.

Kutatásunk középpontjában a településkörnyezet társadalmi-gazdasági rendszerének alrendszere, a kulturális-mentális környezet áll. A kulturális-mentális környezet kifejezi a társadalom környezettel kapcsolatos értékrendjét (a környezetvédelem azonnali cselekvést igénylő, elsődlegesen sürgetô probléma, avagy a gazdasági fejlödésnek kell nagyobb súlyt adni...), eszméit és céljait.

A kulturális-mentális környezet alrendszerének egyik legfontosabb eleme a környezeti tudat. A környezettudat meghatározza az egyének környezettel kapcsolatos szubjektív, nem pontos méréseken alapuló döntéseit, melyeknek „,sokféle következménye van; a gazdaság és a politika szereplöinek is el kell fogadni őket." Ebben a "dimenzióban" születnek és formálódnak a településkörnyezeti rendszer müködésében meghatározó szerepet játszó döntések is, melyek eredménye idővel a gazdasági és épített környezetben válik láthatóvá, hatásuk pedig a természeti és a társadalmi környezetben jelenik meg (Enyedi 2000, 2).

A környezethez füződő értelmi és érzelmi viszony alapján minden emberben más és más környezeti kép alakul ki. Ennél fogva mindenki másként látja a környezetében lezajló eseményeket, különbözően érzékeli a valóságot közelebbi és távolabbi környezetéröl.

A környezeti tudat nem feltétlen jelent tudatosságot. A környezettudatot a kulturális környezet, a társadalmi csoportok értékrendje és az emberek személyiségi összetevői határozzák meg. Az emberek társadalmi helyzetük, gazdasági, politikai, egzisztenciális és egyéb érdekeik szerint „látják és értékelik” a környezeti problémákat (Szirmai 1999). Ebből kiindulva feltételezzük, hogy a településkörnyezeti alrendszerek harmonikus müködésében, a társadalmi tevékenységek környezeti hatá- 
saiban, a környezetszennyezésben és magában a környezetvédelemben is a települések lakosainak gondolkodása alapvetően meghatározó lehet.

A környezeti rendszerek harmóniája, az ökoszisztémák önregeneráló képessége csak és kizárólag az esetben marad fenn, ha az adott térségben valamennyi emberi tevékenység környezettudatos (Kerényi 2000). Vagyis a környezettudatos gondolkodás eredménye az optimális „környezethasználat”, mellyel az ott élök saját biztonságunkat, életminőségủnket határozzák meg. A környezet védelme minden ember számára aktív, mindennapos figyelmet kíván meg. Rendkívül fontos tehát, hogy milyen viszonyban áll az adott személy az öt körülvevő világgal, hogyan dönt azokat a cselekvéseit illetően, amelyek hatással vannak, vagy lehetnek az élő és élettelen környezetre.

A közgondolkodásban a környezeti problémák nem tủkröződnek megfelelően. A konfliktusok összetettségét pedig gyakran egyes kiemelt válságtényezö mögé rejtik. Az emberek nem szeretnek szembe nézni a problémák veszélyeivel, de ami még ennél is rosszabb, hogy még a környezetvédelemben részt vállalók érdekei sem egyértelmủek. Az ökológiai megfontolások célja pedig gyakran nem az egészséges környezet megteremtése, hanem pénzszerzés, vagy éppen politikai, hatalmi tỏke kovácsolása (Szirmai 1999). A környezeti konfliktusok szereplöi lehetnek az állam, az önkormányzatok, a regionális szervezetek, a gazdaság szereplỏi, illetve a civil társadalom. A szereplök vitáiból születỏ rossz döntések, a lakosság tájékozatlansága, a tájékoztatás elmaradása, a környezeti kérdésekben való tartózkodás, a passzivitás ma még általános mind a települési, mind a regionális szinteken.

A Tisza-völgy esetében sem „fedhető le” a környezeti problematika a ciánszenynyezés, vagy az árvizek által okozott károkkal, bár kétségtelen, az évról-évre emelkedő áradások kérdése az elsőszámú környezeti gondot jelenti a folyó mentén ( $S z a-$ bó 2000). Összetettebb regionális környezeti rendszerproblémáról van szó, melyben a természeti elemek sérülése összefüggésben van a különböző konfliktustényezökkel, a térség agrárválságával, az ipari és mezőgazdasági, kommunális hulladékok, a szennyezőanyagok kibocsátásával és elhelyezésével, a helyi társadalom életkörülményeinek a romlásával.

Az aktuális környezetpolitika, az országos stratégiák ma már sok esetben felhívják a figyelmet a települések környezettudatos tevékenységének fontosságára, támogatási alapok születnek a helyi környezeti projektek finanszírozására, államilag preferált programok segítik a vidéki élet fejlődését. Ezek a források azonban a lakosság partnerségének megnyerése nélkül célt tévesztenek. A települések fejlesztésében prioritást kapó környezetvédelem csak akkor ad tényleges hosszú távú fejlödési esélyt, ha a területi ,autonomitás” lehetőségét kihasználók gazdasági törekvései egybeesnek a fenntarthatóságba vetett hittel és a lakosság tudatos, környezetkímélö életvitelének terjedésével. Következésképp a továbbiakban ki kell alakítani azokat a helyi és regionális stratégiákat, amelyek a közgondolkodást jó irányba formálva és építve az emberek környezet iránt érzett felelősségtudatát, erős környezeti lokálpatriotizmusát eredményezhetik. 


\section{A kijelölt mintaterület környezeti viszonyai}

A vizsgált települések a Tisza-völgy Szolnoktól délre eső, Csongrádig tartó szakaszán fekszenek. A terület általános környezeti viszonyai a regionális és lokális környezetvédelmi stratégiák hiányosságából, valamint a határon túli szennyezések drasztikus megnövekedéséből fakadóan rossznak tekinthetök. A rendkívüli vízszennyezések gyakorisága csökkent, de még így is évente tíznél több szennyezéssel kell számolnunk. Ezek kb. 60\%-a hazai, 40\%-a külföldi eredetü. A határon túlról érkezö rendkívüli szennyezések többnyire súlyosabbak, mint a hazaiak (Mezösi 2000). Az utóbbi években jelentkező hatalmas árvizek ugyan ezt a területet kevésbé veszélyeztették, de a mezögazdasági területekre nagy veszélyt jelentő belvizek, ugyanakkor az aszályhajlam megerősödése itt is súlyos környezeti problémaként jelentkezik. A térségben található ipari szennyezőforrások, a bevezetett, $s$ már szigorítottnak tekinthető intézkedések és szabályozók ellenére még mindig nagyban hozzájárulnak a folyó szennyezéséhez, a vízminőség romlásához.

A települések alapvető környezeti gondjai közül az egyik legsúlyosabb probléma a csatornázottság és a szennyvíztisztítás elmaradottsága. A Dél-Tisza-völgyi települések mindössze negyede tekinthetö teljes körúen csatornázottnak, $50 \%$-ukon pedig nincs szennyvíztisztítás. Ezen a téren a városok helyzete jobb, mint a falvaké (1. táblázat).

\section{TÁBLÁZAT}

Szennyvítisztítás és csatornázottság a Tisza menti településeken (Sewage Systems in the Settlements along Tisza)

\begin{tabular}{cccccccc}
\hline & $\begin{array}{c}\text { Települé- } \\
\text { sek }\end{array}$ & Város & Falu & $\begin{array}{c}10000 \\
\text { fó alatti }\end{array}$ & $\begin{array}{c}10000 \\
\text { fö feletti }\end{array}$ & $\begin{array}{c}2000 \text { fö́ } \\
\text { alatti }\end{array}$ & $\begin{array}{c}2000 \text { fö } \\
\text { feletti }\end{array}$ \\
\hline $\begin{array}{c}\text { Van szennyvíz- } \\
\text { tisztító }\end{array}$ & $30,6 \%$ & $100 \%$ & $16,7 \%$ & $22,9 \%$ & $100 \%$ & $7 \%$ & $57,1 \%$ \\
$\begin{array}{c}\text { Nincs szennyvíz- } \\
\text { tisztító }\end{array}$ & $69,4 \%$ & - & $83,3 \%$ & $77,1 \%$ & - & $93 \%$ & $42,9 \%$ \\
\hline
\end{tabular}

Forrás: Fazekas 2000.

További gondot jelent, hogy a Tisza gátjain belül több száz épület van. (Megdöbbentő, hogy ezek többsége építési engedéllyel épưlt!) A gátakon belưli épületekben keletkező szennyvíz nagy része normál vízállások esetén is a Tíszát terheli, s árvíz alkalmával az emésztőkböl kikerülỏ szennyvíz komoly fertőzésveszélyt jelent. A telepủléseken még mindig sok illegálisan müködő fúrt kút van, melyek komoly veszélyt jelentenek a talajvízre, egyes esetekben a vízzáró réteget átütve, a felszín alatti ivóvízbázisokra is. Az EU környezetvédelmi programjának alapvetỏ célkitüzése, hogy a 2000 lakos feletti településeken 2005 -re biztosítva legyen a szennyvíztisztítás lehetösége. A vizsgált településsávon belül a 10000 lakosnál népesebb települések viszonylag megnyugtató helyzetével szemben a 2000 és 10000 fö közötti telepuulések lemaradása igen jelentős. Bár az utóbbi tíz évben megháromszoro- 
zódott azoknak a Tisza menti településeknek a száma, amelyek szennyvíztisztítót használnak, a dinamikus növekedés alapja elsősorban a városi szennyvíztisztítás fokozottabb kiépítése volt (Fazekas 2000).

A települési hulladékok környezetkíméló lerakásának megoldatlansága is az egyre súlyosbodó környezeti veszélyek kðzé tartozik. Az üzemeló hulladéklerakók 60\%-a müködik engedéllyel, 40\%-a engedély nélkül, de az engedéllyel müködők többsége sem felel meg a környezetvédelmi elóírásoknak.

A tájban bekövetkezett változások közül kedvezötlen az erdők tarvágása, a szántóterületek egy részének parlaggá válása (allergén gyomnövények elszaporodása), az illegális hulladéklerakások, a felhagyott kavics- és/vagy homokhányók rendezetlensége.

A társadalmi problémákat a környezeti tudattal kapcsolatba hozó korábbi területi kutatások alapján megállapítható, hogy a folyó menti települések környezeti infrastruktúrájának korszerütlenségén túl jelentősen rontja a helyzetet a prominens személyek ismeretének hiányossága, a lakosság környezeti érzékenységének esetlegessége (Diebel-Szabó 2000; Fazekas-Szabó 2000). „A lakosság érdeklődése igencsak nívó alatti. Az embereknek csak kisebb része érdeklödik a közügyek iránt, maximum $30-40 \%$. A belvizek elhárítását egyértelmüen az önkormányzatok feladatának gondolják. Amikor elöntötte a belvíz a falut és szivattyúztuk ki a vizet a telkekröl, akkor a többség ki se jött megnézni." (Vári 2000)

A lakosság tájékozatlanságán és közömbösségén túl az önkormányzati tisztségviselők környezetvédelmi szakmai tapasztalatának és tudásának a hiánya a települési környezetpolitika elmaradottságának és a környezetvédelem alacsony hatékonyságának az egyik fö okozója. Ezt tuikrözi az a tény, hogy a települések $90 \%$-án nem készült helyi környezetvédelmi program, márpedig a lakosság együttmüködése, környezeti érzékenysége csak úgy növelhető, ha maguk a helyi döntéshozók és vezetők tisztában vannak lakóhelyük gondjaival, a megoldások módjaival. A környezeti infrastruktúra fejlesztése, a lakosság közügyekbe való bevonása sokszor nem anyagi erőforrások, mindinkább lokális környezeti tudatosság és tervezés hiányában marad el.

\section{A környezeti tudatvizsgálat célja, módszere}

A következökben vázolt kutatás fő feladata, hogy feltárja, hogyan vélekednek a folyó menti településeken élők (közvetlenül egy környezeti sokk után) a települések környezetéről, mennyire érzékenyek a globális, a térségi és a helyi környezeti problémákra, s hogyan reagálnak az ezekböl adódó kihívásokra.

A vizsgálat első lépése a tanulmányozott alapsokaság környezeti „orientációjának", környezeti elemekről alkotott tudati vetületeinek mérhetỏvé tétele volt. Leszükítve a környezeti attitủd fogalmát (mely egyaránt magában foglalja az emberek környezethez való viszonyát, szellemi beállítottságát és a környezettel szemben tanúsított magatartását) elsősorban nézöpontokra, véleményekre vonatkozó kérdé- 
Kovács András Donát: A Dél-Tisza-völgy lakosságának környezeti tudata.

Tér és Társadalom, 15. 2001. 3-4. 161-179. p

seket fogalmaztunk meg. A válaszok kiértékelésével a lakosság tudati szintjéről kaptunk képet (de megfelelö módszerek segítségével ez kibővíthető az érzelmi és a cselekvési szintek mérésével is).

Az alapsokaság meghatározásában döntő szerepet játszott a Lakiteleki Népföiskola Tisza Kollégiuma, melynek keretén belül több különbözỏ kutatás zajlott egyetemi hallgatók részvételével. A Szent István Egyetem és az MTA RKK Alföldi Tudományos Intézete által készített és jóváhagyott területi kutatás 22 településen zajlott le. A kutatásba bevont települések a Szolnoktól délre eső Csongrádig húzódó folyószakaszon, a parttól számított $5 \mathrm{~km}$-es távolságon belül helyezkednek el (3. ábra). A lakosság zöme közvetlen vízparti környezetben él. (Ez a folyóhoz való személyes kőtódést már előre sejteti.) A magyarországi statisztikai-tervezési kistérségi beosztásuk szerint Rákócziújfalu, Rákóczifalva, Tiszavárkony, Tószeg, Vezseny, Martfü, Tiszajenő, Nagyrév, Tiszainoka, Csépa, Tiszakürt, Tiszaug, Tiszasas, Tiszaföldvár és Cibakháza a Szolnoki, Csongrád és Csongrád-Bokros a Kunszentmártoni, Lakitelek, Tiszakécske, Tiszakécske-Tiszabög és TiszakécskeKerekdomb a Kecskeméti, Tiszaalpár pedig a Kiskunfélegyházi kistérségen belül helyezkedik el.

\section{3. ÁBRA}

A kiválasztott folyó menti mintaterület települései

(Settlements of the Area along the Selected River)

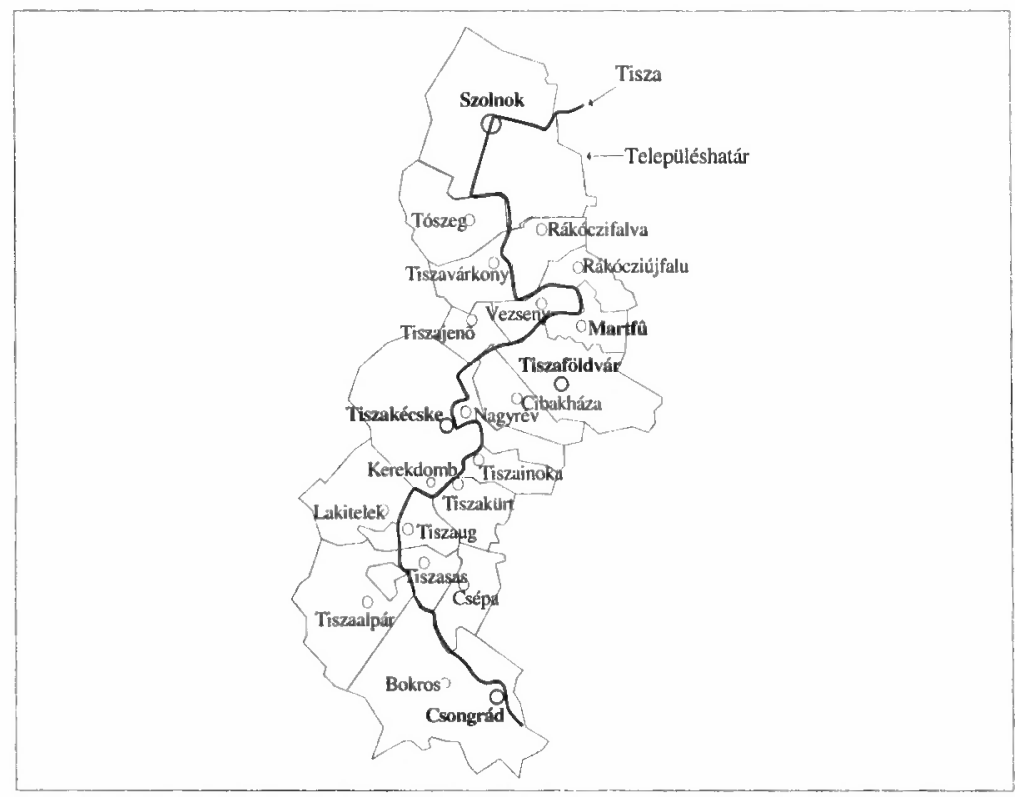

Forrás: Saját szerkesztés. 
A területi felmérés idöpontja 2000. október 13-19. között volt, melyben 85621 fö, a Tisza menti összlakosság 12\%-a képezte a mintavételi alapot. A vizsgálati alapsokaság nagysága és ismert paraméterei alapján településenkénti csoportos mintavételt hajtottunk végre egyszerü véletlen eljárással. A kérdezöbiztosok (egyetemi hallgatók csoportjai) egy véletlen kiválasztási terv (random walk) követésével járták be az adott települések utcáit. Az alapsokaság megosztása a településtípusonkénti népességszám alapján történt, községenként minimum 10 , városok esetén minimum 20 fö került a kiválasztott mintába. A minta statisztikai értelemben vett reprezentativitásának érdekében az alapsokaság paramétereinek tulajdonság kombinációjához utólagos korrekcióval illesztettük a beválogatásra kerülö mintavételi egységeket, melynek eredményeként 364 fö került a mintába. A válaszadók életkori és nemi megoszlásuk, kisebb korrekciókkal iskolai végzettségük szerint is reprezentálják a Tisza mente 15 évesnél idősebb lakosságát. A legfiatalabb válaszadók a középiskolás, míg a legidösebbek a 70 éven feletti korosztályból kerültek ki, 60\%-uk középiskolai, 18\%-uk ennél magasabb végzettséggel. Mivel a lakosság környezethez való viszonya egy adott idöszakaszban statikus, a felmérés keresztmetszeti, alapvetően leíró jellegü.

\section{Környezeti érzékenység, identitás}

A 17 kérdésben megfogalmazott, 66 változót tartalmazó kérdöív alapján történt elemzési munkák kiindulópontja a lakossági független változók és a különböző kérdéscsoportok függő változóinak összevetése volt. Mindenekelőtt arra voltunk kíváncsiak, milyen kapcsolatok tárhatók fel a lakosság nemi, korcsoportos, iskolai végzettségbeli, illetve települési megoszlása és a környezetről alkotott véleményének összefüggésében.

Több kérdés figyelembe vétele alapján megállapitható, hogy a lakosság környezeti tudata nemektöl fuggetlen, vagyis férfiak és nök többnyire azonosan vélekedtek a feltett környezeti kérdésekkel kapcsolatban. Egészen más a helyzet az iskolai végzettség szerinti összehasonlítás esetén. A települések környezeti állapotának, az idegenforgalommal és a mezőgazdasággal kapcsolatos problémák, valamint a társadalmi lehetőségek értékelésében nem mutatható ki jelentős véleménykülönbség az iskolai végzettség függvényében. Ha azonban a nyitott, az általános környezeti problémákra utaló kérdésekre válaszolók csoportját megvizsgáljuk, kiderül, hogy legtöbbjük a föiskolát, egyetemet végzettek közul kerül ki (2. táblázat). A mezögazdasági fejlesztések indoklása és a települések közötti összefogási elképzelésekre vonatkozó - indoklást is igényló - kérdések esetén a válaszolók összetétele 90\%-ban diplomás. A lakosság magasabb iskolai végzettségü csoportjai tehát egyértelmüen érzékenyebben reagáltak a környezeti veszélyeket taglaló kérdésekre (mind a lokális, mind a globális terekre vonatkoztatva). 


\begin{tabular}{|c|c|c|c|c|c|}
\hline \multicolumn{6}{|c|}{$\begin{array}{c}\text { 2. TÁBLÁZAT } \\
\text { Az iskolai végzettség és a környezeti problémákra való érzékenység } \\
\text { összesített kereszttáblája } \\
\text { (Aggregated Crosstable of the Educational Qualification and the Environmental } \\
\text { Sensitivity) }\end{array}$} \\
\hline \multirow{2}{*}{ Iskolai végzettség } & \multicolumn{4}{|c|}{ Lokális és globális környezeti problémák } & \multirow{2}{*}{$\begin{array}{c}\text { Válaszolók } \\
\text { száma }\end{array}$} \\
\hline & érzékeny & érdeklödő & közömbỏs & elutasító & \\
\hline Egyetem & 26 & & 1 & 1 & 28 \\
\hline Föiskola & 25 & 5 & & 1 & 31 \\
\hline Középiskola & 129 & 40 & 41 & 5 & 215 \\
\hline Alacsonyabb végzettség & 19 & 43 & 16 & 12 & 90 \\
\hline Válaszolók száma & 199 & 88 & 58 & 19 & 364 \\
\hline
\end{tabular}

Forrás: Kérdöíves felmérés 2000.

A fiatalabb korosztályok környezeti problémákra való fogékonysága esetén korábbi vizsgálatok alapján szorosabb összefüggést vártunk. Az adott korosztályok válaszaiból kiderül, hogy az alap- és középfokú oktatás ma sem ad kellỏ környezeti ismeretet. Bár a tömegkommunikáció az utóbbi időkben tett néhány lépést környezeti értékeink, az ember-környezet viszonyának fontosságát hangsúlyozó vélemények népszerủsítésében, ez azonban kevés. A környezeti terhelések megnövekedése ellenére a fiatalabb generációk érzékenysége nem igazán nött. Az idösebb lakosság ugyan kisebb mértékben látja aggasztónak közvetlen környezetének gondjait, az ifjabb korosztályok válaszai alapján azonban nem mutatható ki lényegesen magasabb környezeti érzékenység (3. táblázat).

\section{TÁBLÁZAT}

A korosztályok és a környezeti problémákra való érzékenység \%-os arányai (Environmental Sensitivity by Age-groups)

\begin{tabular}{cc}
\hline Korosztályok /életév/ & Aggasztónak látja a környezeti problémákat \\
\hline $15-30$ & $45 \%$ \\
$31-45$ & $38 \%$ \\
$46-60$ & $41 \%$ \\
$61-$ & $34 \%$ \\
\hline
\end{tabular}

Forrás: Kérdőíves felmérés 2000.

A települések környezeti állapotának megítélésében jelentős eltérés mutatható ki a városok és a környezeti infrastruktúra tekintetében hátrányosabb helyzetủ kisközségek között. A lakosság 20\%-a szerint az adott település környezeti állapota rossz, ugyanakkor másik $15 \%$ szerint jó, a maradék $65 \%$ szerint elfogadható, közepes. Ez a vizsgált települések környezeti viszonyainak különbözőségéböl adódik. Az elemzés szerint 95\%-ban a városi kérdezettek tartják jobbnak településük helyzetét.

Vajon Csongrád, Martfü vagy Tiszakécske utcái, terei szebbek, hulladékgazdálkodásuk, szennyvízkezelésük megoldottabb, a lakosság egészségesebb lakókörnyezetben él? 
A környezeti infrastruktúra ismeretében a vizsgált városok környezeti mutatói valóban jobbak. A lakossági közérzet, az általános tájékozottság alapján kialakult vélemények e kérdés esetén viszonylag jól mutatják a települések eltérő helyzetét (4. ábra).

\section{4. ÁBRA \\ A település környezeti allapotának megitélése (Judgement of Environmental Conditions of the Settlement)}

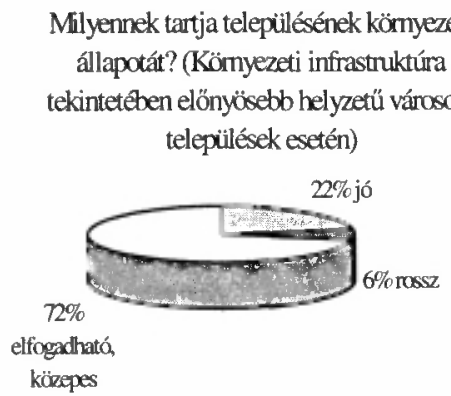

Milyennek tartja telepuilésének kömyezeti
állapotát? (Kömyezeti inyrastruktúra
tekintetében kevésbé fejlett telepuilések
válaszadói szerint)

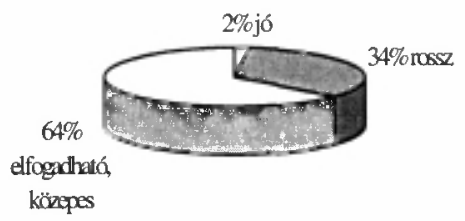

Forrás: Kérdôíves felmérés 2000.

\section{A lakosság lakhelyhez való személyes kötödése}

A környezeti érzet eltérő és változatos dimenzióinak mérésére vezettük be a közvetlen környezetre vonatkozó és az általános környezeti kérdéseket. A legtöbb kérdéssel a lakóhelyet és munkakörnyezetet jelentő élettérhez, a települési környezethez füződő személyes viszonyokat, a lakosság környezeti problémákkal kapcsolatos érzékenységét vizsgáltuk meg.

A lakosság biztonságérzete az árvizeket és a ciánszennyezést követöen ugyan jelentősen csökkent, azonban a folyóhoz való erős érzelmi kötődés az első provokatív kérdést követooen azonnal kirajzolódott. A kérdés, melyben a Tisza és az adott település közelségéböl származó veszélyekre utaltunk, néhány esetben visszatetszést váltott $\mathrm{ki},-\mathrm{a}$,tiszai önérzet” sokakban megszólalt. A kérdezettek több mint fele nem, vagy nem különösen tartotta veszélyesnek lakóhelye folyóhoz való közelségét, ami a települések árvízi veszélyeztetettségét, a védmúvek rossz állapotát (a megfelelő magasságú és állagú töltések aránya nem éri el az 50\%-ot), a szélsőségesen nagy árhullámok levonulását követô kedvezőtlen társadalmi jelenségeket, a folyamatosan csökkenő életszínvonalat figyelembe véve meglehetősen magas arány.

A Tisza mentỉ településsáv kiszolgáltatott, minden egyes áradás alkalmával az árés belvizek természeti, településkörnyezeti hatásai miatt a létbiztonság erősen csökken, az agrártermelési feltételek romlanak, a vízszennyezések miatt pedig visszaesik a turizmus. A társadalmi és természeti környezet negatív változása a térség 
periferizálódását, a társadalmi esélyek romlását hozza magával, ennek ellenére a lakosság többsége nem szándékozik lakhelyet változtatni. A megkérdezettek $85 \%$-a születése vagy évtizedek óta az adott településen él, háromnegyede pedig ugyanazon településen dolgozik vagy végzi napi tevékenységét, $90 \%$-uk pedig továbbra is lakóhelyén akar maradni. A vizsgált területen élők lokálpatriotizmusát (ugyanakkor bizonyos szempontból környezeti figyelmetlenségét, tájékozatlanságát) mutatja, hogy $62 \%$-uk nem különösen, vagy egyáltalán nem tartja társadalmi szempontból hátrányosnak településének földrajzi helyzetét, Tisza-mentiségét. A lakosság, lakhelyhez való személyes kötödése tehát erös. Ez a mentális környezeti adottság talán a Tisza menti települések több száz évre visszavezethető sajátos, folyó menti kultúrájának összetartó erejére vezethető vissza. Ez az erö azonban csak akkor válik a térség erösségévé, ha a tájegység összetett környezeti krízisét, a problémák belső összefüggéseit a helyi társadalom is megérti. A lakosságnak közös célokat kell megjelölnie, s környezeti szakemberek irányításával minden gazdasági döntést szisztematikusan a környezeti értékek megóvásával párhuzamosan kell meghoznia.

\section{Térségi összefogási lehetöségek a lakosság szerint}

A szülöföld iránti kötődés mellett egy másik lényeges vizsgálati tényezỏ a közös problémával való szembekerülés által generált csoporttudat. Áradások alkalmával már számos esetben állt elő olyan vészhelyzet, amely próbára tette a lakosság és a helyi vezetők problémamegoldó képességét és közös tenni akarását. A védekezési munkálatok összekovácsolhatják a helyieket, de a csoportkohézió külső tényezők hatására, évröl évre való hirtelen megnövekedése még nem jelenti a tiszai emberek regionális identitástudatának megerösödését. Jellemző és elgondolkodtató, hogy a települések közötti összefogási lehetöségek tekintetében a kérdezettek tartózkodóvá váltak, a lakosság több mint fele tanácstalan volt, vagy nem adott választ (5. ábra).

\section{5. ÁBRA}

A lakosság által elképzelt, települések közötti kooperációs lehetöségek megoszlása (Distribution of Co-operation Possibilities between the Settlements by the Population)

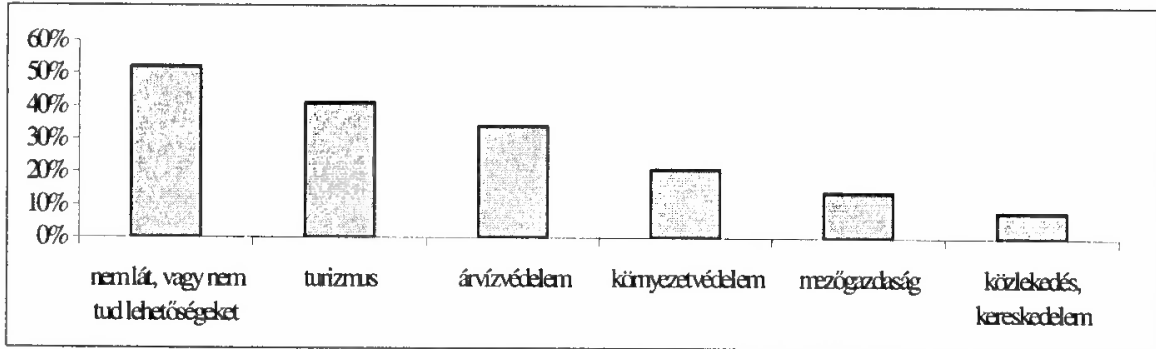

Forrás: Kérdőíves felmérés 2000.

A válaszadók háromnegyede az idegenforgalmi és a vízügyi problémák közös megoldásában látja kistérsége és a Tisza mente közös feladatait. A környezetvé- 
delmi kooperáció (közös szennyvíztelep, hulladékkezelés) gondolata mindössze a lakosság 20\%-ánál merült fel. S talán még megdöbbentőbb, hogy a foglalkoztatottságot tekintve a térségben meghatározó gazdasági ágazat - a mezőgazdaság - terén a kérdezettek mindössze 17\%-a lát együttmüködési eshetöséget. A kooperációs lehetöségek tudatosítása, a kistérségi kapcsolatok megerősítése a települések fenntarthatóságában meghatározó jelentőségủ szempont. A korszerủ települési és regionális együttműködési feltételek megteremtése a jövöben a térség megújulásának egyik alappillére lehet.

\section{A föbb lokális környezeti problémák és azok lakossági megitélése}

A környezeti problémák közül a lakosság a mezögazdasági termöterületek állapotát, a belvízveszély okozta hátrányokat és a szemétlerakás megoldatlanságát látja a legkritikusabbnak (4. táblázat). Egyes tényezők esetén a helyiek érzete nem tükrözi reálisan a tényeket. A szennyvíztisztítás megoldatlanságának, a folyón való átkelés lehetöségének, az árvizek veszélyének jelentőségét alábecsülték. (Ez elsősorban a már korábban említett tájékozatlanságból fakad.)

\section{TÁBLÁZAT}

Tapasztalata szerint, lakóhelyén adnak-e okot aggodalomra az alábbiak? (Do the Followings Give Cause for Worry in Your Settlement in Your Opinion?)

\begin{tabular}{|c|c|c|c|c|c|}
\hline Tényezök & $\begin{array}{l}\text { Nagyon } \\
\text { aggasztó }\end{array}$ & $\begin{array}{l}\text { Eléggé } \\
\text { aggasztó }\end{array}$ & $\begin{array}{c}\text { Nem } \\
\text { nagyon } \\
\text { aggasztó }\end{array}$ & $\begin{array}{c}\text { Egyáltalán } \\
\text { nem } \\
\text { probléma }\end{array}$ & $\begin{array}{l}\text { Nem } \\
\text { tudom }\end{array}$ \\
\hline Az jvóvíz minősége & $15 \%$ & $10 \%$ & $21 \%$ & $50 \%$ & $4 \%$ \\
\hline A Tisza szennyezettsége & $15 \%$ & $45 \%$ & $27 \%$ & $7 \%$ & $6 \%$ \\
\hline A zaj & $4 \%$ & $7 \%$ & $33 \%$ & $50 \%$ & $6 \%$ \\
\hline A levegöszennyezés & $8 \%$ & $12 \%$ & $46 \%$ & $31 \%$ & $3 \%$ \\
\hline A szemétlerakás & $24 \%$ & $30 \%$ & $29 \%$ & $9 \%$ & $8 \%$ \\
\hline A szennyvíztisztítás & $16 \%$ & $29 \%$ & $24 \%$ & $19 \%$ & $12 \%$ \\
\hline $\mathrm{Az}$ árvizek veszélye & $15 \%$ & $33 \%$ & $32 \%$ & $17 \%$ & $3 \%$ \\
\hline A belvízveszély & $26 \%$ & $33 \%$ & $23 \%$ & $14 \%$ & $4 \%$ \\
\hline $\begin{array}{l}\text { A mezőgazdasági termő- } \\
\text { területek állapota }\end{array}$ & $34 \%$ & $21 \%$ & $24 \%$ & $16 \%$ & $5 \%$ \\
\hline $\begin{array}{l}\text { A közlekedés, a forga- } \\
\text { lom nagysága }\end{array}$ & $7 \%$ & $13 \%$ & $27 \%$ & $38 \%$ & $15 \%$ \\
\hline $\begin{array}{l}\text { A folyón való átkelési } \\
\text { lehetőség }\end{array}$ & $15 \%$ & $32 \%$ & $15 \%$ & $30 \%$ & $8 \%$ \\
\hline
\end{tabular}

Forrás: Kérdőives felmérés 2000.

A Szolnok-Csongrád közötti folyószakaszon a falvak többsége a környezeti infrastruktúra kiépítetlensége és az életminőség kedvezőtlen jegyeinek ellenére a Tisza menti más településszakaszokhoz mérten kedvezőbb társadalmi mutatókkal jellemezhető (alacsonyabb munkanélküliség, kisebb arányú elvándorlás). A Tiszza 
mentén viszonylag kedvezöbb gazdasági mutatókkal rendelkezỏ településsáv válaszad6inak fele mégis a munkanélküliséget és az elvándorlást tartotta a negatív folyamatok közül a legsúlyosabbnak. Elszomorító tehát a vélemény, mely szerint településtől függetlenül a kérdezettek 70-80\%-a szerint a munkanélküliség, az életszínvonal csökkenése, a fiatalok elvándorlása problémát jelent (5. táblázat).

\section{TÁBLÁZAT}

A társadalmi jelenségek, mint problémák megitélése (\%)

(Judgement of Social Phenomenon as Problems)

\begin{tabular}{lccccc}
\hline & $\begin{array}{c}\text { Az egyik fö } \\
\text { probléma a } \\
\text { telepúlésen }\end{array}$ & $\begin{array}{c}\text { Problémát } \\
\text { jelent a } \\
\text { település } \\
\text { számára }\end{array}$ & $\begin{array}{c}\text { Nem jel- } \\
\text { lemző a } \\
\text { probléma }\end{array}$ & $\begin{array}{c}\text { Egyálta- } \\
\text { lán nem } \\
\text { probléma }\end{array}$ & $\begin{array}{c}\text { Nem } \\
\text { tudom } \\
\text { megítélni }\end{array}$ \\
\hline Munkanélküliség & 57 & 25 & 13 & - & 5 \\
Életszínvonal csökkenése & 35 & 28 & 33 & - & 3 \\
$\begin{array}{l}\text { Fiatalok elvándorlása } \\
\text { A lakosság passzivitása a }\end{array}$ & 43 & 31 & 14 & - & 12 \\
közúgyekben & 15 & 30 & 45 & 3 & 7 \\
\hline
\end{tabular}

Forrás: Kérdöíves felmérés 2000.

\section{A turizmus és a mezőgazdaság megítélése a térségben}

Sokak szerint a folyóparti települések gazdasági stabilitását a folyóparti adottságokon alapuló turizmus teremtheti meg. Az idegenforgalmi vonzerő megítélése település specifikus volt, de a kérdezettek többsége mindenütt felhívta a figyelmet egy jellemzö ellentmondásra. A vizsgált települések lakossága szerint a legtöbb helyi beruházás a térség gazdaságának egyensúlyban tartásában föszerepet játszó idegenforgalomhoz kötődik. Azonban sok esetben idegen vállalkozók, illetve egykét helyi család kezében összpontosul a vendéglátás, így a lakosság érdekeit ezek a beruházások sem munkahely, sem jövedelem szempontjából nem érintik. Leginkább a pénzhiány gátolja a turizmus fejlödését. A településeken a reklámhiány, az elmaradott infrastruktúra, a rossz megközelíthetőség, a vállalkozások hiánya, a koordináció, a szakmai képzetlenség, a szolgáltatások alacsony színvonala, valamint a lakosság szemlélete is hátráltatja a turizmus kibontakozását.

A térség fenntartható fejlődésének, a helyi társadalom motiválásának egyik fö feltétele a mezőgazdaság és a környezetvédelem együttes fejlesztése. Az új típusú agrárfejlesztések nagyrészt a vidéki gazdálkodók adaptációs készségétől és képességétöl függnek. A Tiszához közeli területeken szükséges mezögazdasági fejlesztések lehetöségeinek megjelölésekor kevesen támogatták a mezőgazdasági és a környezetgazdálkodási szakemberek által a jövőben fontosnak tartott agrárágakat. A tradicionális gazdálkodási módokat, az erdőtelepítések szerepét, a halgazdálkodást és a legeltető állattenyésztést csupán a megkérdezettek 20-20\%-a tartotta fontosnak. Ezzel ellentétben a hullámtéri és ártéri szántók, gyümölcsösök, valamint a múvelésből kivont területek aránya optimalizálásának kérdése érzékenyen érintette 
a többséget. Ezen területek ökogazdálkodási hasznosítását és fejlesztését a lakosság $80 \%$-a fontosnak tartotta.

Korábban végzett felmérés igazolja (Szoboszlai-Szarvák 2000), hogy az önkormányzati vezetök és a környezeti kérdésekben kompetens szakértők többsége az agrárgazdaságot feltétlenül fejlesztendönek tartja a térségben. A három legfontosabb ágazatnak a növénytermesztést, az állattenyésztést és az agrárturizmust jelölték meg. Figyelemre méltó azonban a várható változások irányáról szóló állásfoglalás is. Annak ellenére, hogy a mezögazdasági termékek helyben történő feldolgozását, a mezögazdasági termelök szövetkezését fontos kitörési pontnak ítélik meg, $a z$ önkormányzati vezetoók több mint fele esélytelennek tartotta a lehetöségek realizálását. Nagy esélyt adtak ugyanakkor a mezőgazdasági termékek és szolgáltatások helyi idegenforgalomban történő hasznosításának. Prioritásként jelölték meg a természeti és piaci feltételekhez, valamint a helyi hagyományokhoz és tájadottságokhoz igazodó ésszerü földhasználat és termelési szerkezet kialakítását. Így a szántóterületek csökkentését, a gyepterületek ésszerü hasznositását, a gyümölcsösök területének rekonstrukcióját, a kertészeti kultúrák területének differenciált növelését, a szántóföldi növénytermelés szerkezetének korszerüsítését, a legelöre alapozott szarvasmarha ágazat és juhászat fejlesztését, a halászat fenntartását és az erdőterületek növelését.

Mivel az országos helyzethez képest a mintaterületen a mezögazdasági foglalkoztatottak aránya lényegesen magasabb, a mezö- és erdőgazdaság meghatározó szerepet tölt be a regionális különbségek csökkentésében, az ésszerủ térhasználatban. Ugyanakkor látnunk kell, hogy a rendkívül gyorsan bekövetkező kihívásokra sem a nemzeti agrárpolitika, sem pedig a helyi gazdaságok szereplői mindez ideig nem találtak adekvát válaszokat. Ezek hiánya és az alkalmazkodási zavarok a térségben sok bizonytalansággal terhelik a mezö- és erdőgazdaság jövőképét (Fehér 2000).

\section{A lakossági tájékozatlanság következményei a szennyvizprobléma tükrében}

Saját környezetükről elsősorban tapasztalatok alapján mondtak véleményt a kérdezettek. A sokszor alig müködö helyi információáramlás, a hiányos tapasztalatok miatt a lakosság nem látja át a környezeti problémák összefüggéseit. Ennek egyik bizonyítéka, hogy az aggodalomra okot adó tényezőkre adott válaszokban számos ellentmondás fedezhető fel. A folyóvíz tisztaságát a lakosság 15\%-a nagyon, 45\%-a eléggé aggasztónak tartja, az ivóvízröl azonban csak 25\%-kuknak van hasonlóan rossz véleménye (4. táblázat). A helyiek a vizek tisztaságának megítélésében nem veszik figyelembe, hogy a folyóvíz elszennyeződésével az ivóvízbázisok sérülékenysége is megnövekedhet. Még nagyobb tájékozatlanságra vall, hogy a településeken élök negyede nem tartja aggasztónak a szennyvízkérdést. Ráadásul nem azoknál a településeknél nem törődnek a szennyvízproblémával, ahol ez valamilyen szinten megoldott, hanem legtöbbször ott, ahol a csatornázottság még kialakítatlan.

Vizsgáljuk meg a talajvizek elszennyeződésének példáján, milyen társadalmi következményei lehetnek, ha a lakosság nincs tisztában a település környezeti viszonyaival, teherbíró-képességével. A Tisza mentén az öntözővizek minőségének rom- 
lásában az ipari és mezőgazdasági talajszennyezés mellett a kommunális hulladékok megfelelő elhelyezésének megoldatlansága játssza a fő szerepet.

A vizsgált Tisza menti települések kevesebb mint fele üzemeltet csatornahálózatot, illetve a csatornázott települések kétharmadán további bővítésre van szükség. Annak ellenére, hogy a szennyvízelhelyezésre kijelölt területek kiválasztásánál a környezeti szempontok prioritást élveznek, a Tisza mentén található telepek 70\%-án a környezeti adottságok rendkívül kedvezötlenek. Sok közüluk különösen szennyezés-érzékeny területen helyezkedik el, ahol biztonságos szennyvízelhelyezés nem folytatható. Telephelyi problémákkal küzdenek Tiszaföldváron, ahol hullámtérhez közeli, illetve Rákóczifalván, Lakiteleken és Tiszaalpáron, ahol vízállásos területen, vagy homokgödörben történt hulladék-elhelyezés (Fazekas 2000; Kerényi 2000). A települések többsége rövid időn belül változtatásokat tervez. A szennyvízkezelés megoldatlansága mindig is jobban foglalkoztatta a települések vezetőit, mint a hulladékkezelés, vagy bármely más települési környezeti probléma, azonban az általános érdektelenség és pénzhiány miatt igen nehéz azokat a területi programokat, projekteket megvalósítani, amelyek lakossági összefogást, háztartásonkénti öneröt igényelnének. A térség egyes településein elkészült környezetvédelmi programban is a csatornázottság hiányának problémája került a legelső helyre. Komoly gondot jelenthet, hogy a környezetet leginkább veszélyeztetö szennyvíztelepek fele a 2000 főnél kisebb lélekszámú településen található, vagyis a 2000 fönél kisebb települések $40 \%$-a rendkívül kedvezötlen adottságú területre vezeti el a szennyvízét. Bár az összes - szennyvíztisztítóval még nem rendelkezỏ - 2000 fönél népesebb település hat éven belül szennyvíztisztító építését tervezi, az állami támogatási rendszer ismeretében épp ezen települések helyzete látszik a leginkább kilátástalannak.

A környezeti paradigmaváltás következtében az EU környezetpolitikai feltételei egyre szigorodnak. Figyelembe kell vennünk, hogy a jövőben az uniós élelmiszeripar és piac fóként azoktól a gazdaságoktól fog vásárolni, amelyek biztosítani tudják az egészséges termékeket. Ebböl adódik, hogy a termelők nem engedhetik meg maguknak, hogy szennyezett talajokon, szennyezett vízzel öntözzenek, vagy épp ilyen területekről származó növényekkel takarmányozzák az állatállományt, mivel a káros vegyületek beépülése következtében a szennyezett területekröl származó mezőgazdasági termékek minősége jóval rosszabb, mint a „tiszta környezetből” származóké. Így válik regionális gazdasági kérdéssé az agrárhasznosítású területek környezeti állapota, melynek meghatározó összetevöje a falvak, városok környezetgazdálkodása, a lakosság tisztább környezetért tett erőfeszítéseitől is függő hulladékgazdálkodás és szennyvízkezelés.

Egyetlen település-környezeti elem - a szennyvízelhelyezés megoldatlansága - és a hozzá kapcsolódó környezeti tájékozatlanság kedvezötlen irányba módosítják az egész település-környezeti rendszer müködését. Környezeti gondolkodás és az emberi tevékenységek környezettel való összhangba állítása nélkül gazdasági fenntarthatóság tehát nem képzelhetö el, s mivel az életkörülményeket rendkívül sok környezeti összetevő határozza meg, a kedvezőtlen antropogén behatások által megha- 
tározott folyamatok nemcsak a természeti, de a települési, társadalmi, gazdasági környezet elemeire is visszahatnak.

Mivel a lakosság egy részének fogalma sincs a szennyvízelvezetési problémák káros következményeiről, feltétlenül szükséges a kisebb lélekszámú települések részére egy hosszú távú szennyvízkezelési alternatíva kidolgozása és az ezzel kapcsolatos lakossági tájékoztatás megszervezése, a környezetkímélő szennyvízelhelyezési módok ajánlása, a kistérségi szennyvíztisztítók legkedvezőbb területeken való kijelölésének megkezdése.

\section{Az általános kérdések lakossági megítélése}

Az általános környezeti érzékenység a válaszok alapján egyértelmüen jó irányba mutat. A kérdezettek több mint $85 \%$-a szerint a környezetvédelem azonnali megoldást kíván. Ugyancsak ilyen arányban tartják fontosnak a környezeti fejlesztések, a környezetvédelem szerepét, melyet a gazdaság fejlödése mellett egyidejüleg biztosítani kell.

A válaszadók szerint a komoly környezeti problémák összesített rangsora a következö:

1) Folyók, folyó menti térségek szennyeződése

2) Veszélyes vegyi anyagokat kibocsátó gyárak

3) Világméretủ környezeti károk, trópusi erdők csökkenése, ózonréteg vékonyodása, az üvegházhatás

4) Szennyvizek problémája

5) Szemét az utcákon, zöldterületeken, pihenőhelyeken

6) Ipari hulladékok

7) Növényyvédö-, rovarölő szerek túlzott használata a mezőgazdaságban

8) Atomhulladékok tárolása

9) Savas esők, gépkocsik okozta levegőszennyezés

10) Építkezések, üzemek, nagy forgalom, légi közlekedés okozta zaj

11) Idegenforgalom zsúfoltsága

A sorrend elejére keriult tényezó jól mutatja, hogy környezeti gondolkodásban a személyes környezetet előtérbe helyező szubjektív indíttatás meghatározó lehet, hiszen a válaszolók szeme előtt mindvégig a tiszai környezet „lebegett”, holott a feltett kérdés a globális környezetre vonatkozott.

\section{Zárógondolat}

A környezeti problémák nem vezetnek automatikusan a környezetvédelem kialakulásához. A kömyezeti érdekek alapján formálódó társadalmi igény az, amely képes politikai rendszertöl függetlenül is kialakitani a társadalom és a környezet kapcsolatrendszerét. Az, hogy a településkörnyezeti rendszerekben a környezet-szempontúság dominanciája, vagy a gazdasági aspektusok túlzott előtérbe helyezésével a környezet pusztulása érvényesül, elsősorban a környezetvédelemmel foglalkozó 
szakembergárda és a lakosság felelösségérzetének, anyagiakban és szellemiekben megmutatkozó tenni akarásának függvénye.

A vizsgált mintaterületen a lakosság környezeti érzékenysége mind a személyes, mind a globális térre vonatkoztatva erös, a Közép-Tisza vidéki lakosság környezeti tudatának érzelmi összetevői határozottan pozitív irányban rajzolódnak ki. Ennek ellenére számos kérdés bizonyítja az egyes kulcsfontosságú környezeti problémákkal szembeni tájékozatlanságot és érdektelenséget. Ha az elkövetkezö években ez nem változik, akkor a Tisza-vidék társadalma képtelen lesz környezeti kérdésekben összefogásra, közös érdekérvényesítésre.

A környezetpolitikai intézkedések elmaradása a települések hanyatlását, a településkörnyezeti rendszerek teljesítőképességének rohamos csökkenését hozhatja magával. Meg kell teremteni azokat a társadalmi feltételeket és körülményeket, melyekkel az itt élők szülöföldhöz való ragaszkodása, a folyóhoz füződő szoros érzelmi kötödése hosszú távú környezetkímélö gazdálkodásra váltható, a politika és a gazdaság országos, regionális és lokális szereplőinek pedig észre kell vennie, hogy a Tisza régió egy olyan ökológiai és kulturális tengely, amely az egész Alföld társadalmi-gazdasági jövőjében meghatározó lehet. A Tisza menti településkörnyezeti rendszerek fenntartható fejlődésének ez a záloga.

\section{Irodalom}

Bellon T. (2000) Tisza-vidék kutatás-fejlesztési program 2000. Életmód a Tiszatajon. Tizedik részjelentés. Szeged. Kézirat.

Bognár A. (szerk.) (2000) Sir a Tisza. Masszi Kiadó, Budapest.

Buttel, F. H.(1996) Environmental and Resource Sociology: Theoretical Issues and Opportunities for Synthesis. - Rural Sociology, No. 1. Vol. 61. 56-77. o.

Csatári B.:(1989) A Tiszazug kistérségi problémái. Kutatási jelentés. MTA RKK ATI, Kecskemét. Kézirat.

Csatári B. (szerk.) (2001) A Tisza-vidék problémái és fejlesztési lehetösége. Kutatás-fejlesztési program. MTA RKK ATI, Kecskemét.

Diebel A.-Szabó Gy. (2000) A környezet-és természetvédelem terén tevékenykedõ társadalmi szervezetek kérdöivének értékelése. Debrecen. Tisza program 7. Részjelentés. Kézirat.

Dobossy I.-Kulcsár L.-Virágh E. (1990) A környezeti problémák megoldásának a lehetöségei a lakossági vélemények tükrében. - Környezet és fejlödés. 6. 5-9. o.

Dobossy I. (1991) Környezetvédelem és társadalom. - Környezet és fejlödés. 5. 5-8. o.

Enyedi Gy. (1987) Környezet és társadalom. - Forrás. 1. 1-7. o.

Enyedi Gy. (szerk.) (2000) Magyarország településkörnyezete. Magyarország az ezredfordulón. Stratégiai kutatások a Magyar Tudományos Akadémián. MTA, Budapest. 1-8. o.

Fazekas I. (2000) Kérdöives lakossági környezetvédelmi orientációvizsgálat a Tisza mentén. Részjelentés. Tisza program 7. Debrecen.

Fazekas I.-Szabó Gy. (2000) A Tisza menti települések környezeti állapota, az önkormányzatok környezetvédelmi tevékenysége, feladataik a jövöben. Részjelentés. Tisza program 7. Debrecen.

Fehér A. (2000) Tisza-vidék kutatás-fejlesztési program 2000. A Tisza menti kistérségek részletes erdészeti statisztikai feltárása. Tizennyolcadik részjelentés. Kompolt, Regiocon Kft. Kézirat.

Fodor I.-Kovács B.-Tésits R. (szerk.) (2000) Társadalom és környezet. Konferenciakötet. Dialóg Campus, Budapest-Pécs.

Gallé L. (szerk.) (2000) Természetvédelmi és ökológiai alprogram a Tisza Kiskörétöl délre esö szakaszára. Hatodik részjelentés. SZTE, Szeged.

Horváth J.B. (2000) A forrástól a torkolatig. Sír a Tisza. -Bognár A. (szerk.), Masszi Könyvkiadó, Bp. 86-116. o.

Kerekes S.-Kindler J. (1993-1994) A magyarok és a környezet 1993-ban. Európai Összehasonlítás az Eurobarométer kérdőíve alapján. KKERKK, Budapest. 
Kerényi A. (1995) Általános környezetvédelem. MOZAIK O. S., Szeged.

Kerényi A. (2000) A környezetvédelem stratégiája a Tisza mentén. DTE, Debrecen.

Kerényi A.-Fazekas I.-Szabó Gy. (2001) A környezetvédelem társadalmi megítélése a Tisza mentén egy kérdőíves felmérés európai ósszehasonlításokkal. - Csatári B. (főszerk.) - Rakonczai J.-Tímár J. (szerk.) Alföldi Tanulmányok 2000-2001. Nagyalföld Alapítvány, Békéscsaba. 141-163. o.

Kiss A.-Kovács A. D.-Gaborjákné Vydareny K. (2001) - Csatári B. (Összeáll.) A Tisza-vidék problémái és fejlesztési lehetősége. A Földmúvelési és Vidékfejlesztési Minisztérium Vidékfejlesztési Fõosztálya megbízásából készult Tisza-vidék kutatás-fejlesztési program összefoglalója. MTA RKK Alföldi Tudományos Intézete, Kecskemét.

Kovács A.D. (1999) A környezetvédelmi tudat egyes elemeinek vizsgálata, a svájci Graubünden kanton, valamint két hazai mintaterület alapján. Diplomamunka. KLTE, Debrecen.

Mezősi G. (2000) Tisza-vidék kutatás-fejlesztési program 2000. A Tisza-vidék fejlesztését befolyásoló vizrajzi kockázatok, eröforrások és lehetőségek Tizenkettedik részjelentés. Szeged SzTE Természeti Földrajzi Tanszék. Kézirat.

Rozgonyi T.-Tamás P.-Tamási P.-Vári A. (szerk.) (2000) A tiszai árvíz. MTA Szociológiai Kutatóintézet, Budapest.

Somogyi S. (szerk.) (2000) A XIX. századi folyószabályozások és ármentesitések földrajzi és ökológiai hatásai Magyarországon. MTA Földrajztudományi Kutatóintézet, Budapest.

S Ráđuly J. (2000) A gyilkos arany. - HVG. február 19. 15. o.

Szabó J. (szerk.) (2000) Természetvédelmi és ökológiai alprogram a Tisza országhatártól Kisköréig terjedõ szakaszára. DTE Környezetvédelmi Központ, Debrecen.

Szirmai V. (1999) A környezeti érdekek Magyarországon. Pallas Stúdió, Budapest.

Szoboszlai Zs.-Szarvák T. (2000) Prominens személyiségek véleménye a Tisza-vidékfejlesztésekröl. Negyedik részjelentés. MTA RKK ATI, Szolnok.

Vári A.-Rozgonyi T.-Tamás P. (szerk.) (2000) A tiszai árvíz. MTA Szociológiai Kutatóintézet, Budapest. 